\title{
EFFECT OF DIFFERENT CONCENTRATIONS OF MULBERRY LEAVES ON DIABETIC RATS
}

\author{
By \\ Romia Soliman El Daly \\ Home Economics Department, \\ Faculty of Specific Education in \\ Damietta, Mansoura University, \\ Egypt. \\ Ghada Mosad El Seedy \\ Home Economics Department, \\ Faculty of Specific Education in \\ Damietta, Mansoura University, \\ Egypt.
}

Research Gournal Specific Fducation

Faculty of Specific Education

gMansoura University

ISSUE NO. 28, JANUARY. 2013

مجلة بحوث التزبية النوعية ـ جامعة المنصورة

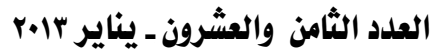




\title{
EFFECT OF DIFFERENT CONCENTRATIONS OF MULBERRY LEAVES ON DIABETIC RATS
}

\author{
Romia Soliman El Daly" \\ Ghada Mosad El Seedy
}

\section{Abstract}

The present study aimed to investigate the effect of different concentrations from Mulberry leaves of rats suffering from diabetes. Twenty male Albino rats Sprague Dawley strain weighing $(140 \pm 10 \mathrm{~g})$ injected with (150mg) alloxan $/ \mathrm{Kg} \mathrm{b.w)} \mathrm{to} \mathrm{induce} \mathrm{diabetic.} \mathrm{they} \mathrm{divided} \mathrm{into} \mathrm{four} \mathrm{groups}$ one of them fed on basil diet as positive control group, the other group fed on basil diet and treated orally daily with different concentration from Mulberry leaves 10,15,20\% for five weeks . Sensory evaluation was three food items by 10 non-dependent diabetes people, also biological evaluation and estimating the biochemical analysis for liver function, kidney function, and blood glucose, as well as blood glucose was analyzed daily to all samples throughout the experiment period. The mean value of serum glucose of rats were significant, uric acid values of all groups were also significant. the mean values of serum GOT, GPT and alkaline phosphates for all groups were lower than the control.The mean values of BWG. For all rats were significant as compared with the control group. Concluded from the above that the Mulberry leaves by the different average 10,15, 20\% led to a significant decrease in blood glucose, and recommend using Mulberry leaves a remedy for patients with diabetes non-dependent.

* Home Economics Department, Faculty of Specific Education in Damietta, Mansoura University, Egypt. 


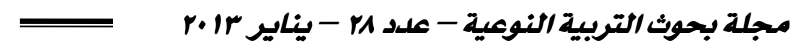

\title{
EFFECT OF DIFFERENT CONCENTRATIONS OF MULBERRY LEAVES ON DIABETIC RATS
}

\author{
Romia Soliman El Daly" \\ Ghada Mosad El Seedy
}

\section{INTRODUCTION :}

Young Mulberry leaves and Twigs are a high quality fodder, readily accepted by all classes of stock gives the following table. Composition of Moradabad, White Mulberry leaves as (\%) of dry matter (Sanche Z., 2002)

Table (1) Chemical composition of Mulberry leaves in Indian

\begin{tabular}{|l|c|c|c|c|c|c|}
\hline & Protein & Fiber & Ash & Fat & Ca & P \\
\hline Fresh mulberry leaves & 15.0 & 15.3 & 14.3 & 7.4 & 2.42 & 0.24 \\
\hline
\end{tabular}

Mulberry leaves contain n-containing sugars, rutin, quercetin, volatile oil, amino acid, vitamins and microelements, which have so many pharmacological activities such as reducing blood glucose, antihyperlipidemia, hypertensive, bacteriostasis and antivirus. There are plentiful Mulberry leaves in China and there would be a bright developing and studying future of functional foods and it was found that composition of the Mulberry leaves. Chemical contains several vital material and chemical compounds have the same composition chemical to insulin, which works to burn excess sugar in the body Zou and Chen, (2003).

Mulberry leaves is one of the traditional Chinese herbs. There are various effective ingredients in Mulberry leaves. They are mineral constituents, vitamins, food fiber, amino acid, plant sterols, flavones, alkaloids, and polysaccharides; and so on Mulberry leaves have such physiological function as lowering blood glucose. Lowering blood pressure, Lowering cholesterol, resisting decrepitude, keeping digestive and excretory system healthy, preventing and resisting cancer, improving the immune ability. The research progress on chemical constituents and physiological functions of Mulberry leaves in recent years both at home and abroad is

* Home Economics Department, Faculty of Specific Education in Damietta, Mansoura University, Egypt. 
summarized and the exploitation and utilization of Mulberry leaves in the field of health care are reported in this paper Wang and Lijian, (2005).

\section{MATERIALS AND METHODS:}

\section{Materials:-}

Mulberry Leaves obtained from the Fruit Garden in Damietta. Alloxan obtained from Research Institute of Ophthalmology Medical Analysis Department, Giza, Egypt. Experimental animals, mal albino rats (SpragueDawley white) weighing $140 \pm 10 \mathrm{~g}$ were obtained from the Research Institute of Ophthalmology Medical Analysis Department, Giza, Egypt.

\section{METHODS:}

Mulberry leaves were cleaned thoroughly by washing and sensory evaluation. Were the Following items of tea, stuffing pies and vegetable by 10 people. Sensory evaluation has been applied by questionnaire (Watts et al., 1989).

\section{Biological Part:}

Albino rats, Sprague Dawely strain weighting $140 \pm 10 \mathrm{~g}$.

\section{Basal diets:}

The basal diet was prepared according to the following formula as mentioned by AIN, (1993).

\begin{tabular}{||c|c||}
\hline \hline Ingredients & Standard diet (\%) \\
\hline \hline protein & 20.0 \\
Sunflower oil & 10.0 \\
Mineral mixture & 4.0 \\
Vitamins mixture & 1.0 \\
Puree of date palm & 10.0 \\
Corn starch & 55.0 \\
\hline \hline Total & 100 \\
\hline
\end{tabular}

Vitamin mixture components:

The used vitamin mixture component was that recommended by Campbell (1963). 
Vitamin mixture components

\begin{tabular}{||c|c|c|c||c||c||}
\hline Ingredients & Amounts & Ingredients & Amounts & Ingredients & Amounts \\
\hline \hline Vitamin A & $300 \mathrm{IU}$ & Riboflavin (B2) & $1.0 \mathrm{mg}$ & Inosital & $5.0 \mathrm{mg}$ \\
Vitamin D & $100 \mathrm{IU}$ & Pyridoxine & $1.0 \mathrm{mg}$ & Para-amino benzoic acid & $5.0 \mathrm{mg}$ \\
Vitamin E & $10 \mathrm{IU}$ & Pantothenic acid & $3.0 \mathrm{mg}$ & Cyano cobalamin (B12) & $0.00135 \mathrm{mg}$ \\
Vitamin K & $2.25 \mathrm{mg}$ & Niacin & $4.5 \mathrm{mg}$ & Biotin & $0.02 \mathrm{mg}$ \\
Menadion & $1.0 \mathrm{mg}$ & Choline chloride & - & Folic acid & $0.09 \mathrm{mg}$ \\
Thiamine (B1) & & & & Dextrose & $77.13865 \mathrm{mg}$ \\
\hline
\end{tabular}

\section{Mineral mixture components:}

Salt mixture used was formulated to (Hegested, 1941).

Mineral mixture components

\begin{tabular}{|c|c|}
\hline Compounds & Quantity (g / kg salt) \\
\hline \hline $\mathrm{CaCO} 3$ & 300 \\
$\mathrm{KH} 2 \mathrm{PO} 4$ & 322 \\
$\mathrm{CaPO} 42 \mathrm{H} 2 \mathrm{O}$ & 75 \\
$\mathrm{MgSO} 47 \mathrm{H} 2 \mathrm{O}$ & 102 \\
$\mathrm{NaCl}$ & 167 \\
$\mathrm{FeC6H} 6 \mathrm{O} 7.6 \mathrm{H} 2 \mathrm{O}$ & 27.5 \\
$\mathrm{KI}$ & 0.9 \\
$\mathrm{MnSO} 4.4 \mathrm{H} 2 \mathrm{O}$ & 5 \\
Zn Cl2 & 0.25 \\
$\mathrm{CuSO} 4.5 \mathrm{H} 2 \mathrm{O}$ & 0.35 \\
\hline \hline Total & 1000 \\
\hline
\end{tabular}

\section{Preparation of diabetic rats}

\section{Diabetic rats:}

Diabetes was indicted in normal healthy male albino rats by intraperitoneal injection of alloxan $150 \mathrm{mg} / \mathrm{kg}$ body weight. According to the method described by (Desai and Bhide, 1985) 
One week after obtained were samples blood the injection of alloxan, fasting to estimate fasting serum glucose. Rats having fast. Serum glucose more than 190mg/dI.were considered diabetics (NDDG, 1994).

\section{Experimental design}

Twenty Sprague Dawley white male albino rats, weighting about $140 \pm 10 \mathrm{~g}$ were used. The animals were obtained from Giza. Rats $(\mathrm{n}=20$ rats) were housed in wire cages under the normal laboratory condition and fed on basal diet for a week as adaptation period. Diet was given in nonscattering feeding cups to avoid loss or Contamination of food, Water was provided to the rats by means of glass tubes projecting through the wire cage from an inverted bottle supported to one side of the cage.

The rats were divided into 4 groups each of 5 rats. The groups of rats were as follows:

- Group (1) Hyperglycemic control positive group, in which alloxan injected rats fed on basal diet.

- Group (2) Hyperglycemic group fed on basal diet+10\% Mulberry leaves.

- Group (3) Hyperglycemic group fed on basal diet+15\% Mulberry leaves.

- Group (4) Hyperglycemic group fed on basal diet+20\% Mulberry leaves.

\section{Biological evaluation:}

During the experimental period (5weeks) the consumed feed was recorded every day, and body weight recorded weekly. The body weight gain (B.W.G \%), food efficiency ratio (F.E.R.) and also organs weight were determined according to Chapman et al., (1959) using the following equations.

B W G $\%=\frac{\text { Final weight }(\mathrm{gm})-\text { initial weight }(\mathrm{gm}) \%}{\text { Initial weight }}$

$$
\text { FER }=\frac{\text { Gain in body weight }(\mathrm{g})}{\text { Food Intake }(\mathrm{g})}
$$




\section{a- Organs weight:}

Heart, liver and kidneys, of the sacrificed rats were carefully removed, washed in saline solution, dried with filter paper and weighted in dependently organs weight as percentage of final body weight were calculated .

\section{b-Blood sampling and organs :}

At the end of the experimental period blood samples were collected after 12 hours fasting from the portal vein; the rats were scarified after being ether anesthetized. Blood samples were received into clean dry centrifuge tubes, and left to clot at room temperature, then centrifuged for 10 minutes at $3000 \mathrm{rpm}$ to separate the serum.

Serum was carefully aspirated and transferred into clean curve $t$ tubes and stored frozen at $20^{\circ} \mathrm{C}$ for analysis Malhotra, (2003)

At the same time, the organs: Heart, liver and kidneys removed, cleaned weighted and stored in formalin solution (10\%) for histopathological investigation as the method mentioned by Drury and Wallington, (1980)

\section{Biological analysis:}

a-The level of sugar was measured in the blood of the all rats weekly using a measurement of sugar.

b-Determination of serum glucose:

The Principle use of glucose determination according to Trinder, (1969).

\section{Determination of liver function:}

1-Alkaline phosphatase: Enzymatic colori metric determination of alkaline phosphatase was corried out according to Belfieled and Goldberg, (1971).

2-Determination of GPT (ALT): Determination of GPT was carried out according to the method of Tietz, (1976).

3-Determination of (AST): Determination of GPT was carried out according to the method of Henry,(1974) and Yound, (1975). 


\section{Determination of kidney functions:}

\section{1-Creatinine :}

\section{Principle:}

Creatinine in alkaline solution reacts with picric to form a colored complex. The amount of the complex formed is directly proportional to the Creatinine concentration according to Larsen, (1972).

\section{2- Uric acid:}

\section{Principle:}

The principle use of uric acid determination according to Carawy, (1955)

\section{Statistical analysis:}

Statistical analysis were performed by using computer program, statistical package for social science (SPSS, 1998), and compared with each other using the suitable tests.

\section{RESULTS:}

\section{Sensory evaluation:}

Table (2) showed mean values for aroma, taste, color, tenderness and Overall acceptability for all food items, results showed That tea and stuffing pies at the highest rats of acceptance, Tea from sample $(18.70 \pm 0.26,38.60 \pm$ $0.42,8.80 \pm 0.20,8.70 \pm 0.21,19.20 \pm 0.24$, respectively and stuffing pies from sample $(6.20 \pm 0.29,38.10 \pm 0.45,8.40 \pm 0.30,8.40 \pm 0.26,18.60 \pm 0.26$, respectively).where the results were as follows for the vegetable(17.60 $\pm 0.33, \quad 37.40 \pm 0.40, \quad 7.70 \pm 0.36, \quad 7.50 \pm 0.34, \quad 17.70 \pm 0.36$, respectively)and all food items from Mulberry leaves showed a highly significant $(\mathrm{p}<0.05)$. 
Table (2): Sensory evaluation of the arbitrators on the food items form the Mulberry leaves

\begin{tabular}{|c|c|c|c|c|c|c|c|c|c|c|c|}
\hline \multirow[t]{2}{*}{ No. } & \multirow[t]{2}{*}{ Treatments } & \multicolumn{2}{|c|}{$\begin{array}{c}\text { Aroma } \\
20\end{array}$} & \multicolumn{2}{|c|}{$\begin{array}{c}\text { Taste } \\
40\end{array}$} & \multicolumn{2}{|c|}{$\begin{array}{c}\text { Color } \\
10\end{array}$} & \multicolumn{2}{|c|}{$\begin{array}{c}\text { Tenderness } \\
10\end{array}$} & \multicolumn{2}{|c|}{$\begin{array}{c}\text { Overall } \\
\text { acceptability } \\
20 \\
\end{array}$} \\
\hline & & $\mathrm{M} \pm \mathrm{SE}$ & Sd. & $\mathrm{M} \pm \mathrm{SE}$ & Sd. & $\mathrm{M} \pm \mathrm{SE}$ & Sd. & $\mathrm{M} \pm \mathrm{SE}$ & Sd. & $\mathrm{M} \pm \mathrm{SE}$ & $\mathrm{Sd}$. \\
\hline 1 & Tea & $\begin{array}{c}18.70 \pm 0.2 \\
6\end{array}$ & 0.82 & $\begin{array}{c}38.60 \pm \\
0.42\end{array}$ & 1.34 & $\begin{array}{c}8.80 \\
\pm 0.20\end{array}$ & 0.63 & $\begin{array}{r}8.70 \\
\pm 0.21\end{array}$ & 0.67 & $\begin{array}{r}19.20 \\
\pm 0.24\end{array}$ & 0.78 \\
\hline 2 & $\begin{array}{c}\text { Stuffing } \\
\text { Pies }\end{array}$ & $\begin{array}{l}18.20 \\
\pm 0.29\end{array}$ & 0.91 & $\begin{array}{l}38.10 \\
\pm 0.45\end{array}$ & 1.44 & $\begin{array}{r}8.40 \\
\pm 0.30\end{array}$ & 0.96 & $\begin{array}{r}8.40 \\
\pm 0.26\end{array}$ & 0.84 & $\begin{array}{l}18.60 \\
\pm 0.26\end{array}$ & 0.84 \\
\hline 3 & Vegetable & $\begin{array}{l}17.60 \\
\pm 0.33\end{array}$ & 1.07 & $\begin{array}{l}37.40 \\
\pm 0.40\end{array}$ & 1.26 & $\begin{array}{r}7.70 \\
\pm .36\end{array}$ & 1.15 & $\begin{array}{r}7.50 \\
\pm 0.34\end{array}$ & 1.08 & $\begin{array}{l}17.70 \\
\pm 0.36\end{array}$ & 1.15 \\
\hline
\end{tabular}

\section{Biological evaluation:}

Table (3) showed the mean and SD value of body weight gain (BWG $\%$ ) for control and different groups of rat fed on Mulberry leaves. As for the mean value of body weight gain was high significantly higher $(\mathrm{p}<0.05)$ than the control group results were being $(13.6 \pm 1.99,14.65 \pm 2.27,13.3 \pm 2.24$, and $6.83 \pm 1.03$ respectively) for all rats groups fed on Mulberry leaves. Regarding food efficiency ratio, it was high significantly higher $(\mathrm{p}<0.05)$ than the control group results were being $(0.79 \pm 0.09,0.88 \pm 0.13,0.80 \pm 0.12$ and $0.51 \pm 0.07$, respectively) for rats groups fed on Mulberry leaves.

The mean value of food intake (FI) for all rat group was significantly higher $(\mathrm{p}<0.05)$ than the control group results were being $(17.04 \pm 0.45$, $16.46 \pm 0.27,16.5 \pm 0.31$, and $13.18 \pm 0.89$, respectively). 
Table (3): The mean and SD value of different concentration of Mulberry Leaves on Body Weight Gain of experimental rats

\begin{tabular}{|c|c|c|c|c|}
\hline parameters & Control & $\begin{array}{c}\text { Mulberry } \\
\text { Leaves10\% }\end{array}$ & Mulberry Leaves $15 \%$ & $\begin{array}{c}\text { Mulberry } \\
\text { Leaves } 20 \%\end{array}$ \\
\hline BWG\% & -6.83 & 13.60 & 14.65 & 13.3 \\
\hline Mean \pm SD & \pm 1.05 & \pm 1.99 & \pm 2.27 & \pm 2.24 \\
\hline $\mathrm{T}$.test & & -23.01 & -14.62 & -20.55 \\
\hline Sig. & & 0.00 & 0.00 & 0.00 \\
\hline Food intake(g) & 13.18 & 17.04 & 16.46 & 16.5 \\
\hline Mean \pm SD & \pm 0.89 & \pm 0.45 & \pm 0.27 & \pm 0.31 \\
\hline $\mathrm{T}$.test & & -7.33 & -11.03 & -7.03 \\
\hline Sig. & & 0.002 & 0.00 & 0.002 \\
\hline F.E.R & -0.51 & 0.79 & 0.88 & 0.80 \\
\hline Mean \pm SD & \pm 0.07 & \pm 0.09 & \pm 0.13 & \pm 0.12 \\
\hline $\mathrm{T}$.test & & -25.14 & -14.82 & -20.17 \\
\hline Sig. & & 0.00 & 0.00 & 0.00 \\
\hline
\end{tabular}

B.W.G.: Body weight Gain

F.I : Food Intake

F.E.R. : Food efficiency ratio

Table (4) showed the mean and SD value of different concentration of Mulberry leaves on organs weight of Experimental rats. Mean weight of Kidney weight was no significant, mean value of liver weight of all group were significant $(\mathrm{p}<0.001)$ and mean value of heart weight of Mulberry leaves $20 \%$ was significant $(\mathrm{p}<0.05)$. 
Table (4): The Mean and SD value of different concentration of Mulberry Leaves on Organs Weight of experimental rats

\begin{tabular}{|c|c|c|c|c|}
\hline Organs weight & Control & $\begin{array}{c}\text { Mulberry } \\
\text { Leaves10\% }\end{array}$ & $\begin{array}{c}\text { Mulberry } \\
\text { Leaves } 15 \%\end{array}$ & $\begin{array}{c}\text { Mulberry Leaves } \\
20 \%\end{array}$ \\
\hline Kidney weight & 1.28 & 1.14 & 1.26 & 1.20 \\
\hline Mean \pm SD & \pm 0.08 & \pm 0.15 & \pm 0.05 & \pm 0.10 \\
\hline $\mathrm{T}$.test & & 1.51 & 0.343 & 1.63 \\
\hline Sig. & & 0.20 & 0.74 & 0.17 \\
\hline Liver weight & 4.76 & 5.38 & 8.38 & 5.16 \\
\hline Mean \pm SD & \pm 0.05 & \pm 0.14 & \pm 0.08 & \pm 0.16 \\
\hline $\mathrm{T}$.test & & -9.34 & -12.65 & -5.16 \\
\hline Sig. & & 0.001 & 0.000 & 0.007 \\
\hline Heart & 0.77 & 0.82 & 0.78 & 0.78 \\
\hline Mean \pm SD & \pm 0.04 & \pm 0.08 & \pm 0.08 & \pm 0.04 \\
\hline $\mathrm{T}$.test & & -0.89 & -0.04 & -1.00 \\
\hline Sig. & & 0.35 & 0.89 & 0.00 \\
\hline
\end{tabular}

Table (5) showed the mean values blood glucose of rats fed on $10 \%$ 15\%-20\%Mulberry leaves was significantly $(\mathrm{P} \leq 0.05)$ as compared with the control $(280.8 \pm 2.77 \mathrm{mg} / \mathrm{dl})$ results were $92.80 \pm 3.34,80.2 \pm 2.38$ and $75.20 \pm 4.96 \mathrm{mg} / \mathrm{dl}$, respectively. As for creatinine values of rats fed on 10\%$15 \%-20 \%$ Mulberry leaves was higher than the control $(0.72 \pm 0.10 \mathrm{mg} / \mathrm{dl})$ was results $0.88 \pm 0.05,0.85 \pm 0.07$ and $0.81 \pm 0.10 \mathrm{mg} / \mathrm{dl}$, respectively. Regarding the mean values uric acid of rats fed on 10\%-15\%-20\% Mulberry leaves was significantly $(\mathrm{P} \leq 0.05)$ as compared with the control $(3.10 \pm 0.14$ $\mathrm{mg} / \mathrm{dl}$ ) results were $4.644 \pm 0.11,4.34 \pm 0.24$ and $3.78 \pm 0.38 \mathrm{mg} / \mathrm{dl}$, respectively. These results agree with that of wang and lijian (2005) 
Table (5) the mean and SD value of Blood glucose and Kidney Function for control different groups of fed on Mulberry leaves with three treatments

\begin{tabular}{|c||c|c|c|c||}
\hline \hline Treatments & Control & $10 \%$ & $15 \%$ & $20 \%$ \\
\hline \hline parameters & 280.8 & 92.80 & 80.2 & 75.20 \\
Blood glucose mg/dl)) & \pm 2.77 & \pm 3.34 & \pm 2.38 & \pm 4.96 \\
Mean \pm SD & & 94.0 & 120.7 & 78.4 \\
\hline T .test & & 0.00 & 0.00 & 0.00 \\
\hline Sig. & 0.72 & 0.88 & 0.85 & 0.81 \\
Creatinine mg/dl)) & \pm 0.10 & \pm 0.05 & \pm 0.07 & \pm 0.10 \\
Mean \pm SD & & -1.30 & -6.50 & -3.13 \\
\hline T .test & & 0.26 & 0.00 & 0.03 \\
\hline Sig. & 3.10 & 4.644 & 4.34 & 3.78 \\
SD & \pm 0.14 & \pm 0.11 & \pm 0.24 & \pm 0.38 \\
\hline Uric acid (mg/dl) Mean \pm & & -18.28 & -14.2 & -3.83 \\
\hline Tig. & & 0.00 & 0.00 & 0.01 \\
\hline \hline
\end{tabular}

Figure (1)showed that the rats fed on Mulberry leaves various percentage of $10 \%, 15 \%, 20 \%$ per day led to significant decrease in blood glucose was better and led to decline in the proportion is $20 \%$ wile the percentage of blood glucose in the control group is very high. These results agree with that of Zou and Chen, (2003).

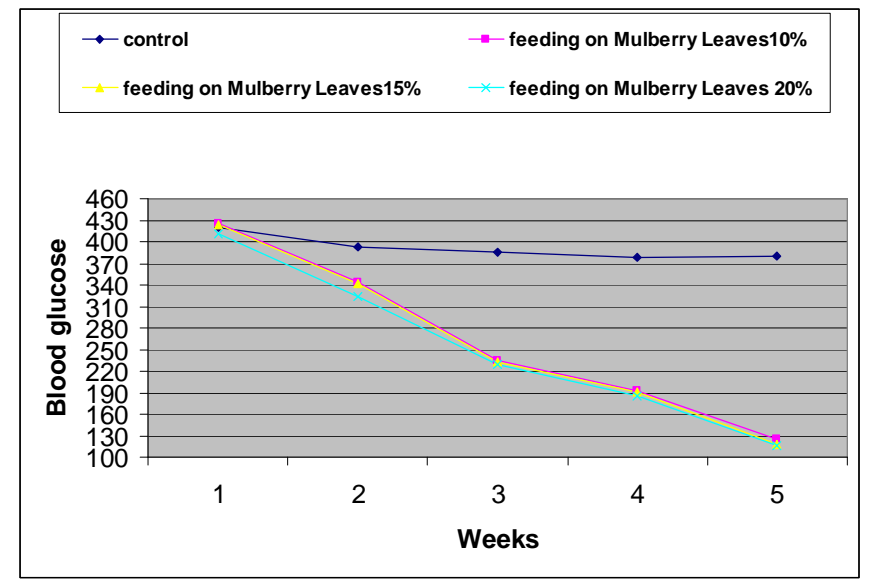

Fig. (1)The average of blood glucose for control and different groups of rats fed on Mulberry leaves various percentages 
Table (6) showed the mean values of serum GOT of rats fed on $10 \%$ ,15\% , 20\% Mulberry leaves were lower than the control (104.8 $\pm 8.9 \mathrm{IU} / \mathrm{I})$ results were $103.2 \pm 8.8,101 \pm 4$.4and $98.4 \pm 4.8 \mathrm{IU} / \mathrm{I}$ respectively .The mean value of serum GPT of rats fed on $10 \%, 15 \%, 20 \%$ Mulberry leaves were lower than the control $(62.4 \pm 3.93 \mathrm{IUI} / \mathrm{I})$ results were being $56 \pm 3.04,43.0 \pm 4.1$ and $39.0 \pm 9.5 \mathrm{IU} / \mathrm{I}$, respectively .As the mean value of alkaline phosphates for all groups were lower than the control group $(821 \pm 38.4 \mathrm{IIU} / \mathrm{I})$ results were being $550 \pm 38.7,400 \pm 15.8,228 \pm 19.2 \mathrm{IU} / \mathrm{I}$, were significant $(\mathrm{p}<0.05)$. These results agree with that of Wang and lijian (2005)

Table (6) the mean and SD value of liver function for control and different groups of rats fed on Mulberry leaves with three treatments

\begin{tabular}{||c||c|c|c|c||}
\hline parameters & Control & $10 \%$ & $15 \%$ & $20 \%$ \\
\hline \hline GOT (IU/l) & $\begin{array}{c}104.8 \\
\text { Mean } \pm \text { SD }\end{array}$ & $\begin{array}{c}103.2 \\
\pm 8.8\end{array}$ & $\begin{array}{c}101 \\
\pm 4.4\end{array}$ & $\begin{array}{c}98.4 \\
\pm 4.8\end{array}$ \\
\hline T .test & & -1.09 & -0.40 & -3.36 \\
\hline Sig. & & 0.33 & 0.33 & 0.02 \\
\hline GPT (IU/l) & 62.4 & 56 & 43.0 & 39.0 \\
Mean \pm SD & \pm 3.93 & \pm 3.04 & \pm 4.1 & \pm 9.5 \\
\hline T .test & & 3.93 & -2.08 & 1.85 \\
\hline Sig. & & 0.01 & 0.01 & 0.13 \\
\hline Alkaline phosphates & 821 & 550 & 400 & 228 \\
(IU/l) Mean \pm SD & \pm 38.4 & \pm 38.7 & \pm 15.8 & \pm 19.2 \\
\hline T .test & & 12.83 & 39.08 & 32.69 \\
\hline Sig. & & 0.00 & 0.00 & 0.00 \\
\hline \multicolumn{1}{|c||}{} & & & \\
\hline
\end{tabular}




\section{References}

- AIN (1993): American Institute of Nutrition Purified Diet for Laboratory Rodent, final report, J. Nutrition, 123: 1939 - 1951 and O. Compactum Benth, J. Essential Oil Res., 8 (6): 657 - 664.

- Belfield, A. And Goldberg, D.M. (1971): Alkaline phosphates colorimetricmethod.J. of Enzyme (12), 561

- Campbell, J. A., (1963); Methodology of Protein Evaluation RAG Nutri. Document R. 10L Ed., 37. June Meeting New York

- Chapman, D.G., castilla, R. And campbll, J.A. (1959): Evaluation of protein in food. I.A. method for the determination of protein efficiency ratio. Can. J. Biochem. Physiol., 37: 679 - 686.

- Carawy, W. (1955): Uric acid colorimetric method, Am. J.Clin. (25), 840.

- Desai, N.S.and Bhide, H. G. (1985): Hypoglycemic effect of Hantitonia Suave lens. Indian. Med., 81: 86-91.

- Drury, R.A. and Wallington, E.A. (1980): Carton's Histological Technique 5th Ed, Oxford University.

- Hegested, A., (1941): Salt mixture. J. Biol. Chem., 138: 459.

- Henry, R.J. (1974): Clinical Chemist principles and Technics, 2nd eddition, Hagers town (MD), Harcer, Row, p.8802 (1974).

- Larsen, K. (1972): Creatinine color emitrickinetic method. Of Clin. Chem., (41): 209.

- Maihotra, V.K. (2003): Practical Biochemistry for students, Fourth Edition, Jaypee Brothers Publishers (P) LTD, New Delhi.

- N.D.D.G Nation Diabetes Data Group. (1994): Densification and diagnosis of diabetes mellitus and other categories of glucose intolerance.J of Diabetes, 28:1039-1057.

- Spss (1998): Statistical Pakage for Social Science, Computer Software, Ver. 10. Spss Company. London, UK.

- Sanchez, M.D., (ed.) (2002): Mulberry for Animal Production FAO Animal Production and Health paper. 147:329-331.

- Tietz, N.W (1976): Fundaentals of Clinical Chemistry. Philadelphia, W.B. sunders p. 243. 


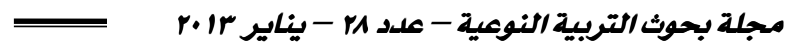

- Trinder .P. (1969): Determination of blood glucoses using 4- amino phenasone J.Cline .Path, 22:246.

- WANGF ang, LIjian - rong. (2005): Research Progress on Chemical Constituents Physiological function and Application of Mulberry Leaves. Food science. 1002-6630.0.2005-s1-030.

- Watts, B.M., yamaki, G.L., Jeffery, L.E. and Elias, L.G. (1989): Basic Sensory Methods for Food Evaluation. 1st Ed., the international Development researches terpub., Ottawa, Canada

- Yound, D.S. (1975): Determination of Got.J. Chem., 21:1.

- Zou Sheng-gin, CHENwu. (2003): A review on Chemical Constituents, Pharm a Co logical Activity and Application of Mulberry Leaves. Journal of Chemical industry of Forest Products, 1005- 3433.O.2003-01-008. 


\section{تأثير تركيزات هنتلفة هن ورق التوت على الفئران المصابة بهرض السكر}

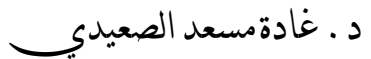

د. رومية سليمازالدالجي

\section{الملخص}

تهدف هذه الدراسـة إلى بحـث تأثير تركيزات مختلفــة مـن ورق التوت على الفئـران المصابة

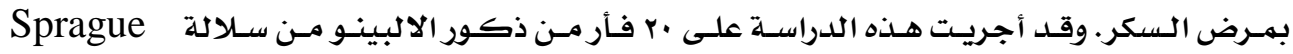

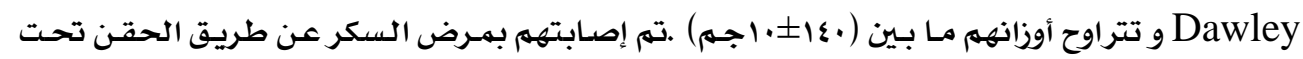

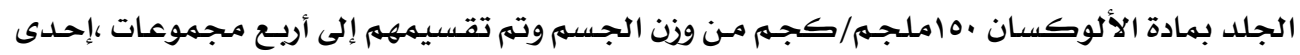

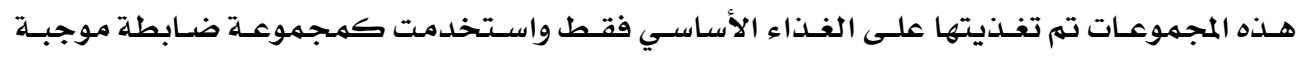

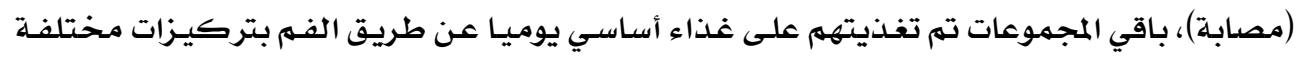

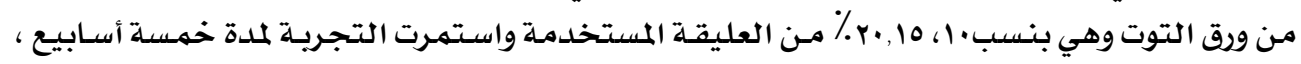

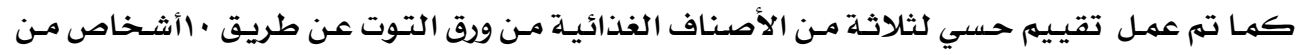

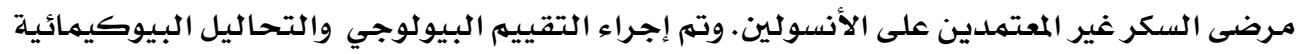

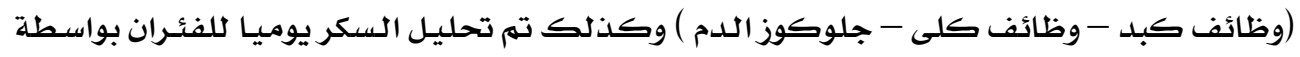

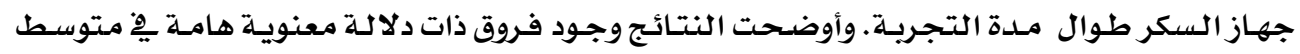

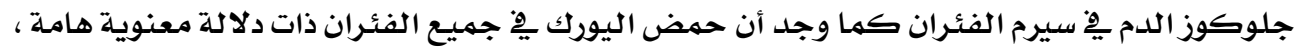

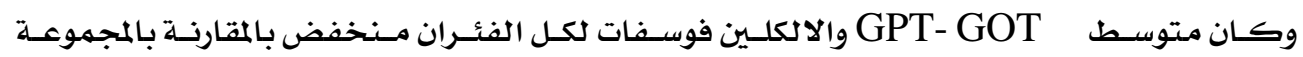

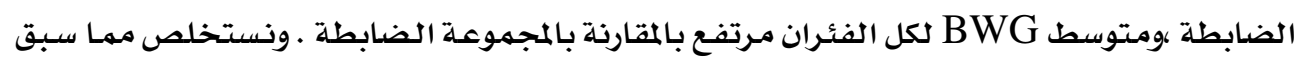

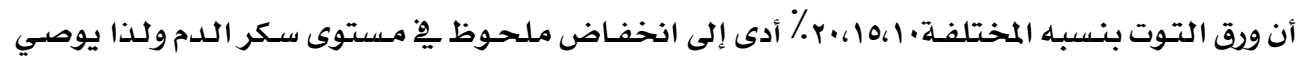

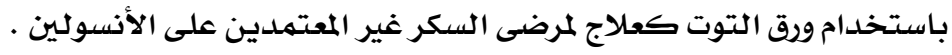

